\title{
Treaty caution on plankton plans
}

The scientific advisory group for the parties of the London Convention, the main treaty governing ocean dumping, has for the first time questioned the use of 'iron fertilization' in combating climate change. The group's statement, released on 22 June, will not in itself interfere with plans by Planktos, a San Francisco-based company, to create a large plankton bloom with the technique in the coming months. But this official statement of concern could strengthen calls for further regulation under the terms of the treaty when the partners meet later this year.

The London Convention advisory group, which includes representatives from 19 parties to the convention, as well as various observers, says in its public statement that "knowledge about the effectiveness and potential environmental impacts of ocean iron fertilization currently is insufficient to justify large-scale operations".

Although there has been research into iron fertilization over the past decade, just how much carbon such blooms sequester is still unclear. A key complicating factor is that much of the resulting biomass may be converted back to carbon dioxide through grazing by other organisms. Scientists

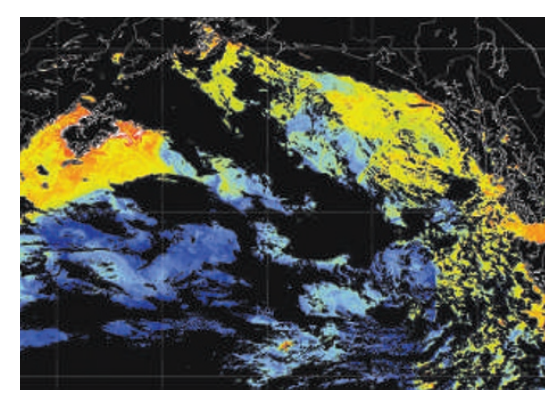

Experiments that use iron to seed plankton blooms (yellow) are visible from space. experiments in favour of more reactive forms of the metal. The company intends to study the seeded area during the six months the bloom is expected to persist, and Planktos says it wants to involve outside scientists in the project. However, according to George, "countless false and harmful statements being presented in the world media" about the company's work have made such collaborators hard to find.

David Kubiak, a spokesman for Planktos, says that, in addition to gathering data, the company hopes to sell 'carbon credits' based on the Galapagos work, subject to outside verification that carbon really is being stored and not rereleased. He adds that if between 2.5 million and 4.5 million tonnes of carbon were sequestered, and buyers could be found, the company might make up to $\$ 25$ million.

Ken Johnson, a leader of past iron-enrichment research who works at the Monterey Bay Aquarium Research Institute in California, says the estimate is in line with the more optimistic estimates for ratios of bloom carbon to iron, but that other estimates may be two orders of magnitude lower. "The gist of it is we don't know if it's viable or not."

Although Johnson is adamant that such work and environmentalists have also raised concerns about potential side effects, including the growth of harmful algal species and the depletion of oxygen as a result of bacterial breakdown of the phytoplankton.

Planktos's plan to seed an area roughly 560 kilometres west of the Galapagos Islands would make it the first commercial company to conduct large-scale iron fertilization, although other for-profit groups are also pursuing the idea. Planktos's president, Russ George, says the experiment is designed in large part to answer the very questions raised by the advisory group.

Others disagree. "I think selling [the Planktos project] as research is really quite disingenuous," says David Santillo of the Greenpeace Research Laboratories in Exeter, UK. Greenpeace has campaigned against commercial iron fertilization, and George believes such efforts led to the advisory group taking up the issue.

Planktos plans to release 90 tonnes of haematite, an iron-containing mineral that, although readily available as an industrial waste product, has been passed over in scientific should be done by governments, not commercial organizations, he thinks iron fertilization should remain an option for controlling greenhouse gases if it can be made to work. "It's probably not good," he says, "but is it worse than doing nothing at all?"

With the issue of iron fertilization now officially raised by the advisory group's statement, the parties to the London Convention may opt to clarify related legal issues at their next meeting include amending the convention or for signatory countries to amend their respective ocean dumping laws.

Concern in the United States that the Galapagos experiment might use a non-USflagged ship and thus avoid US regulation was what led the United States to request that the London Convention scientific group consider the issue. Dale Kemery, a spokesman for the US Environmental Protection Agency, says that, regardless of the ship used, the United States might still have jurisdiction if the iron to be released originated there.

Mark Schrope in London in November. Their options would

\section{SCORECARD}

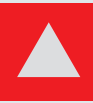

Mushrooms

Fungi may soon become the latest addition

to the menu for eco-builders, thanks to Rensselaer Polytechnic graduates Eben Bayer and Gavin McIntyre, who have invented organic household insulation tiles that use mushrooms as their key ingredient.

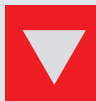

\section{BlackBerrys} French defence experts have warned senior

government staff not to use the hand-held e-mail devices for official business, citing fears that the messages, which pass through servers in Britain and the United States, are not safe from spies.

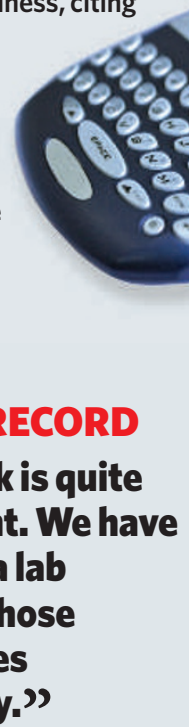

ON THE RECORD

(CThe work is quite unpleasant. We have to stay in a lab smelling those awful gases repeatedly.)

Liu Jingcai, one of China's new 'professional noses', who have been trained to sniff out dangerous pollution in the southern industrial town of Panyu.

\section{NUMBER CRUNCH}

103 is the average IQ of adults who were born first among their siblings, according to a Norwegian study.

100 is the average IQ of secondborn children, showing that older siblings generally grow up to be the cleverest.

4 is the number of older siblings of Charles 'father of biology' Darwin, proving that there's no accounting for genius.

Sources: Associated Press, Reuters, Science 